\title{
Hubungan Kandungan Nitrat Dan Fosfat Dalam Substrat Terhadap Kerapatan Lamun Di Perairan Pantai Prawean, Jepara
}

\author{
Achmad Yusuf Subiakto*, Gunawan Widi Santosa, Suryono, Ita Riniatsih \\ Departemen IImu Kelautan, Fakultas Perikanan dan Ilmu Kelautan, Universitas Diponegoro \\ JI. Prof.H.Soedarto S.H, Tembalang,Semarang, Jawa Tengah 50275 Indonesia \\ *Corresponding author, e-mail : yusufsubiakto@gmail.com
}

\begin{abstract}
ABSTRAK : Senyawa nitrat dan fosfat merupakan nutrien yang dapat dijadikan sebagai petunjuk kesuburan perairan dan dibutuhkan baik pertumbuhan dan perkembangan lamun. Nutrien di perairan padang lamun berperan sebagai faktor pembatas pertumbuhan. Penyerapan nutrien oleh lamun dilakukan oleh daun dan akar. Besarnya kandungan nutrien dalam sedimen bukan berarti akan selalu dalam konsentrasi yang sama pada karakteristik sedimen dasar dan kedalaman perairan. Bila terjadi perbedaan maka hal ini bisa mempengaruhi terjadinya perbedaan kondisi kepadatan dan sebaran pada setiap jenis lamun yang tumbuh dalam perairan, oleh karena itu perlu dilakukan penelitian tentang hubungan kandungan Nitrat dan fosfat dalam substrat terhadap kerapatan lamun di perairan pantai Prawean, Jepara. Penelitian ini dilakukan pada bulan Desember 2018- Januari 2019. Metode penentuan lokasi pengambilan sampel dengan metode purposive sampling. Materi yang digunakan dalam penelitian adalah sampel sedimen, parameter perairan, dan kerapatan lamun. Berdasarkan hasil penelitian didapatkan Nilai kandungan Nitrat di substrat Perairan Pantai Prawean Jepara berkisar antara 1,27-1,36 mg/L tergolong pada kategori kesuburan rendah. Nilai kandungan Fosfat pada sedimen yaitu 0,049-0,086 $\mathrm{mg} / \mathrm{L}$ tergolong pada kategori rendah hingga tinggi. Tingkat kerapatan padang lamun berada pada kondisi kerapatan sangat rapat (>175 tegakan/m2).
\end{abstract}

Kata Kunci: Nutrien; Nitrat; Fosfat; Substrat; Kepadatan Lamun

\section{Relationship of Nitrate and Phosphate Content in Substrate to Seagrass Density in Prawean Coastal Waters, Jepara}

\begin{abstract}
Nitrate and phosphate compounds are nutrients that could be used as an indicator of aquatic fertility and needed by for growth and development of seagrass. Nutrients in seagrass waters serve as a limiting factor for growth. Nutrient absorption by seagrass were done by leaves and roots. The amount of nutrient content in sediment does not mean would be always same at the concentration on the basic sediment characteristics and depth water level. If there is a difference, it will cause an affect the different conditions of density and distribution in each type of seagrass which grows in the waters, therefore it is necessary to do research about relation of nutrient in the substrate to seagrass density in Prawean Beach, Jepara. This research was conducted in December 2018 - January 2019. The method used in this study was descriptive method. The material used in the study were sediment samples, water parameters, and seagrass density. Based on the results, it was found that the value of nitrate in substrate in the waters of Prawean Jepara Beach ranged from $1.27-1.36 \mathrm{mg} . \mathrm{L}^{-1}$ belonging to the low fertility category. The value of Phosphate content in substrate was $0.049-0.086 \mathrm{mg} . \mathrm{L}^{-1}$ belonging to the low until high category. The density level of seagrass at the tight density condition very tight $>175$ stands. $m^{-2}$.
\end{abstract}

Keywords : Nutrients; Nitrate; Phosphate; Substrate; Seagrass Density

\section{PENDAHULUAN}

Nutrien merupakan zat hara yang penting dalam menunjang proses pertumbuhan dan perkembangan potensi sumberdaya ekosistem laut. Fosfat merupakan nutrisi esensial bagi pertumbuhan suatu organisme perairan, jika konsentrasi fosfat di perairan tinggi maka 
mengindikasikan adanya zat pencemar. Kadar nitrat dipengaruhi oleh asupan nitrat dari badan sungai. Nitrat berasal dari pertanian termasuk kotoran hewan dan manusia.

Ketersediaan nitrat dan fosfat di perairan padang lamun dapat berperan sebagai faktor pembatas pertumbuhan sehingga efesiensi daur nutrisi dalam sistemnya akan menjadi sangat penting untuk melihat produktivitas primer padang lamun dan organisme autrotofnya (Hillman et al., 1989). Konsentrasi nitrat dan fosfat yang larut dalam perairan pada daerah tropis lebih rendah jika dibandingkan dengan konsentrasi nutrien yang ada di sedimen (Fachrul, 2005). Sebagaimana diketahui bahwa di dalam substrat mengandung beberapa unsur zat hara diantaranya nutrien yang berpengaruh dalam pertumbuhan dan perkembangan lamun.

Pantai Prawean terletak di Kecamatan Jepara, Kabupaten Jepara, tepatnya di Desa Bandengan. Kawasan ini sebagai tempat specific tourism (keindahan lamun), tempat sandar perahu nelayan, kapal wisatawan, tempat sandar kapal PT Pura Bahari, sawah dan pemukiman warga. Kawasan ini mayoritas sebagai tempat mata pencaharian nelayan lokal. Pantai Prawean terdapat hamparan lamun yang cukup luas yang menjadi salah satu ekosistem yang penting di perairan tersebut. Pada bulan Desember Pantai Prawean terlindung dari musim baratan, yang mengakibatkan pada bulan tersebut padang lamun di perairan Pantai Prawean masih dapat dijumpai dalam jumlah yang banyak. Penelitian hubungan kandungan nitrat dan fosfat dalam substrat terhadap kerapatan lamun di Pantai Prawean perlu dilakukan karena jika nitrat dan fosfat tidak terpenuhi secara baik akan mengakibatkan gangguan seperti perbedaan kerapatan dan sebaran lamun. Nitrat dan fosfat juga penting dalam menunjang proses pertumbuhan dan perkembangan potensi sumber daya ekosistem padang lamun di kawasan ini.

\section{MATERI DAN METODE}

Materi yang digunakan pada penelitian ini adalah komunitas lamun dan habitatnya meliputi substrat dan air sebagai media hidupnya. Penentuan lokasi penelitian menggunakan teknik pengambilan purposive sampling. Gambar 1 menunjukkan lokasi pengambilan data di Perairan Pantai Prawean Jepara. Pada lokasi penelitian terdapat 3 stasiun pengambilan dan setiap stasiun terdapat 3 sub stasiun berdasarkan sumber nitrat dan fosfatnya. Stasiun 1 berada di Pantai yang sering dikunjungi masyarakat, Stasiun 2 di tempat penambatan perahu nelayan, pelabuhan PT Pura Bahari dan Tambak, Stasiun 3 berada didekat pemukiman warga dan Sawah.

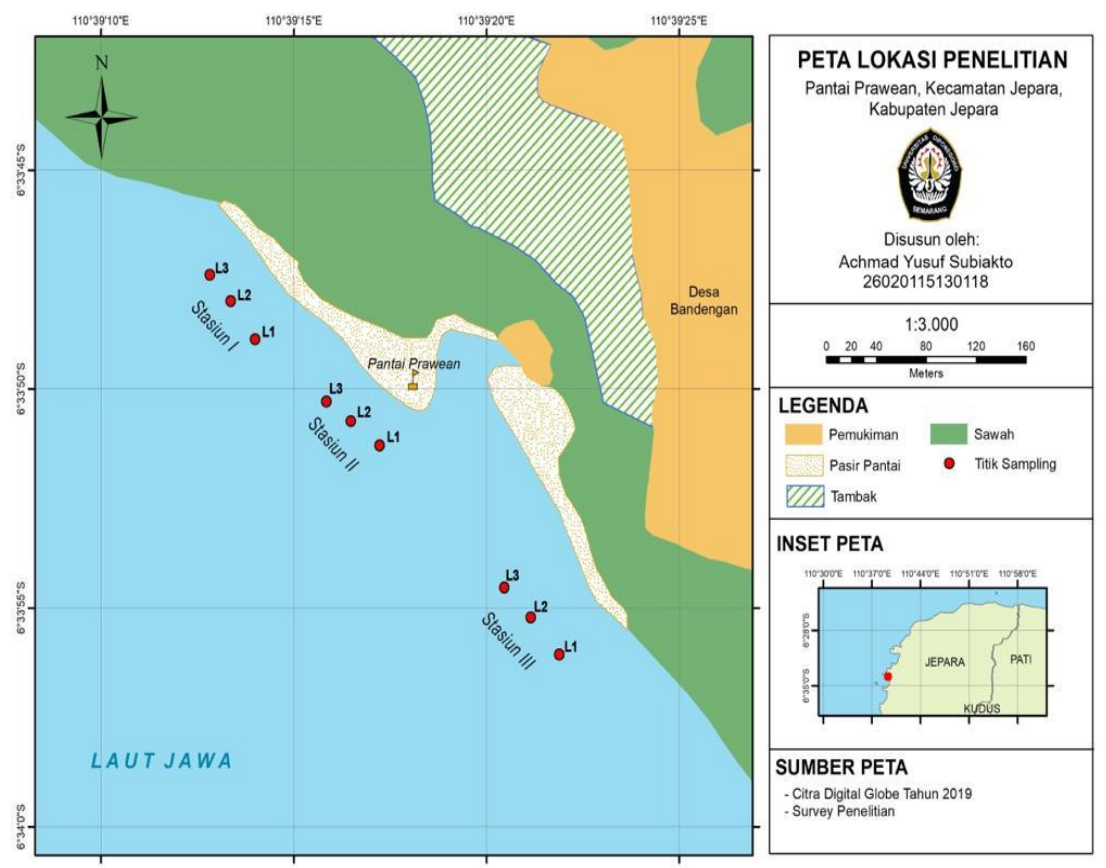

Gambar 1. Peta Lokasi Penelitian di Pantai Prawean 
Pengambilan substrat menggunakan core dari pipa paralon berukuran jari-jari $5 \mathrm{~cm}$ dan panjang $30 \mathrm{~cm}$. kemudian core ditancapkan pada kedalaman $10 \mathrm{~cm}$ (metode core sampling) kemudian substrat untuk analisis Nitrat Fosfat yang didapatkan disimpan dalam ziplock dan kemudian disimpan pada coolbox dan diberi es batu selama perjalanan menuju laboratorium dan diberi penanda pada setiap sub stasiun. Untuk analisis Nitrat dan Fosfat dilakukan di Laboratorium Balai Pengujian dan Peralatan Dinas Bina Marga dan Cipta Karya Provinsi Jawa Tengah untuk menetukan analisis kadar nitrat (SNI 06-6989.31-2005) dan fosfat (BP2-MU-A-08) metode spektrofotometri. Untuk pengambilan sampel analisis Granulometri pengambilanya menggunakan sekop kemudian sampel dimasukkan ke dalam ziplock dan dilakukan pengujian di lanoratorium mekanika tanah Fakultas teknik Universitas Diponegoro Semarang.

Pengamatan lamun meliputi; identifikasi jenis, kerapatan, pengukuran penutupan. Pengamatan dilakukan dengan metode seagrasswatch (2003). Line Transect quadrant dibentang secara tegak lurus terhadap garis patai kearah laut sepanjang 50 meter, yang dimulai dari titik 0 (nol) atau pertama kali ditemukanya lamun. Setiap stasiun terdapat 3 sub stasiun yang berjarak 25 meter sejajar dengan garis pantai. Transek kuadrat yang digunakan ukuran 1x1m modifikasi dari seagraswatch. Kemudian di catat identifikasi, jumlah tegakan dan penutupan. Acuan yang digunakan untuk identifikasi jenis lamun menggunakan buku Status Padang Lamun dari COREMAP-CTI dan P2O-LIPI tahun 2017. Parameter perairan yang diukur yaitu, Salinitas, Ph, Suhu, Oksigen Terlaurt (DO), Kecepatan arus dan Kecerahan dilakukan secara in-situ pada setiap stasiun dan dilakukan 3 kali pengulangan.

Nilai kerapatan lamun dihitung dengan rumus (English et al., 1997) yaitu jumlah total tegakan individu jenis lamun dibagi luas total pengambilan. Penutupan Lamun dihitung dengan menjumlahkan seluruh nilai penutupan lamun pada seluruh kuadrat dibagi jumlah kotak pengambilan. Untuk mengetahui hubungan antara kandungan nitrat dan fosfat terhadap kerapatan lamun dilakukan uji analisis regresi linier berganda dengan menggunakan software SPSS 16.

\section{HASIL DAN PEMBAHASAN}

Nilai konsentrasi nitrat tertinggi berada pada Stasiun III dan terkecil pada Stasiun II. Stasiun I memiliki rerata sebesar $1,35 \pm 0,15 \mathrm{mg} / \mathrm{L}$, pada Stasiun II memiliki kandungan rearata 1,27 $\pm 0,2$ $\mathrm{mg} / \mathrm{L}$ dan Stasiun III kandungan rerata nitrat sebesar 1,36 $\pm 0,17 \mathrm{mg} / \mathrm{L}$. Rendahnya nitrat pada lokasi penelitian ini diduga karena substrat pada setiap lokasi penelitian didominasi oleh pasir. Stapel et al., (1996) yang menyatakan semakin kasar ukuran butir substrat maka semakin rendah pula kandungan nutrien didalamnya kebalikanya semakin halus ukuran butir substrat maka semakin tinggi pula kandungan nutriennya. Hasil analisis nitrat pada substrat paling tinggi berada pada statsiun III yaitu sebesar $1,36 \mathrm{mg} / \mathrm{L} \pm 0,17 \mathrm{mg} / \mathrm{L}$ berada di dekat perumahan dan sawah, dimana kandungan nitrat pada substrat diduga dipengaruhi oleh masukan limbah rumah tangga dan limbah pertanian sawah. Menurut Raymont (1961) pengaruh konsentrasi nitrat (mg/l) dengan pertumbuhan organisme rendah pada kisaran $0,3-0,9 \mathrm{mg} / \mathrm{L}$, optimum pada $0,9-3,5 \mathrm{mg} / \mathrm{L}$ dan membahayakan pada $>3,5 \mathrm{mg} / \mathrm{L}$. Berdasarkan hasil penelitian ini pengukuran nitrat belum membahayakan biota laut, masuk dalam kategori optimum. 


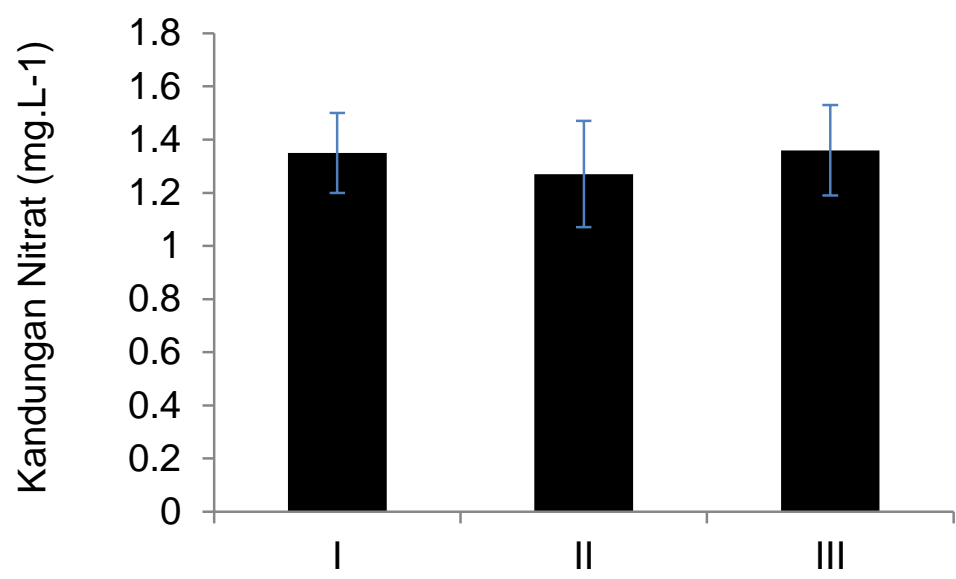

Gambar 2. Kandungan Nitrat pada Substrat

Kandungan Fosfat pada gambar 3 dapat dilihat bahwa pada tiga stasiun penelitian menujukkan kandungan Fosfat pada sedimen berkisaran antara 0,023 - 0,1 mg/L. konsentrasi tertinggi berada pada Stasiun III dan terkecil pada Stasiun I. Stasiun I memiliki rerata sebesar $0,046 \pm 0,12 \mathrm{mg} / \mathrm{L}$, pada Stasiun II memiliki rerata $0,050 \pm 0,019$ dan Stasiun III rerata nitrat sebesar 0,086 $\pm 0,009 \mathrm{mg} / \mathrm{L}$.

Kandungan fosfat tertinggi didapatkan pada stasiun III yaitu berkisar 0,086 $\mathrm{mg} / \mathrm{L} \pm 0,009$ dipengaruhi oleh masuknya nutrien dari daratan, adanya masukan limbah pertanian sawah melalui saluran air. Menurut Bennet et al. (2001) sumber fosfat di perairan dan sedimen berasal dari: deposit fosfor, industri, limbah dari daratan, aktivitas pertanian, pertambangan batuan fosfat, dan penggundulan hutan. Kadar fosfat dalam sedimen lebih tinggi dibandingkan dalam air karena pada sedimen, fosfat akan terendapkan. Kadar fosfat yang ditemukan disebabkan oleh kondisi lingkungan pada masing-masing lokasi. Kandungan fosfat tinggi yang ditemukan di lokasi penelitian disebabkan oleh pencampuran massa air tawar hasil buangan limbah masyarakat dari darat berupa limbah pertanian dan limbah rumah tangga yang bercampur dengan air laut dan terakumulasi dalam substrat. Difusi fosfat dari substrat dapat mengakibatkan tingginya fosfat, karena substrat merupakan tempat penyimpanan utama fosfat di perairan.

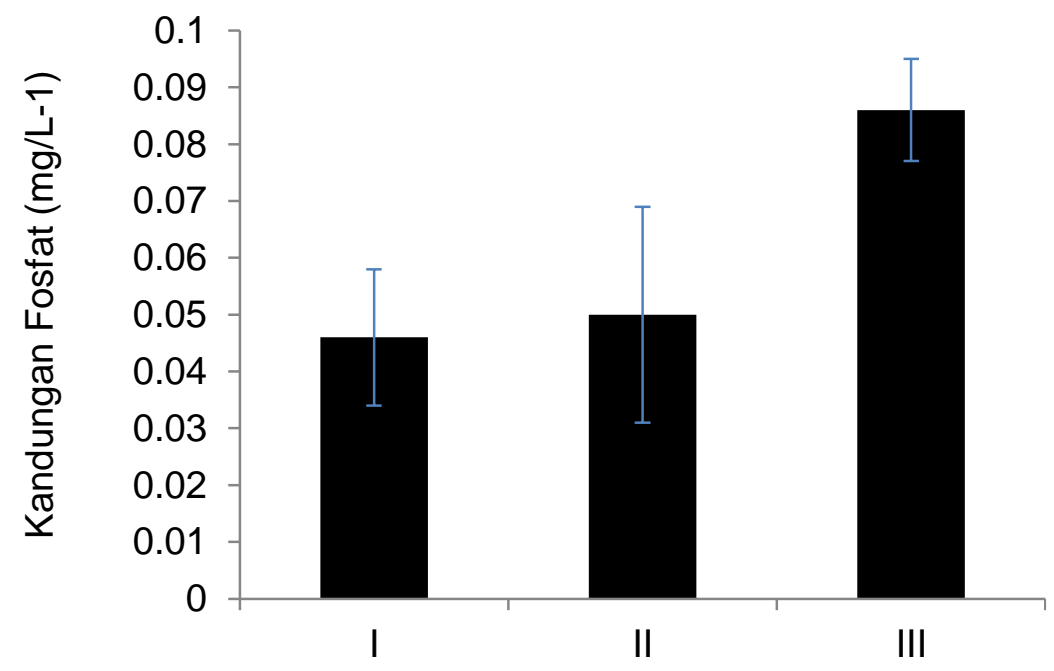

Gambar 3. Kandungan Fosfat pada Substrat

Kerapatan lamun yang didapatkan berkisar antara 228,66- 363,32 tegakan $/ \mathrm{m}^{2}$. Kepadatan lamun Jenis Cymodocea serrulata tinggi bersubstrat pasir. Diduga jenis substart pasir merupakan daerah yang disukai lamun jenis tersebut untuk hidup. Sesuai dengan pernyataan Yunitha et al. (2014) bahwa jenis lamun Cymodocea serrulata mampu hidup pada sedimen jenis pasir. 
Kerapatan Cymodocea serrulata yang ditemukan pada stasiun I, II, dan II menunjukkan kecocokan karakteristik habitat. Tomascik et al. (1997) menyatakan bahwa keberadaan lamun disuatu perairan tergantung pada kondisi perairan atau habitat lamun dapat tumbuh. Jenis lamun juga mempengaruhi kerapatan laun itu sendiri, sesuai dengan pernyataan Hartati, dkk, (2012) menyatakan bahwa kerapatan tegakan lamun dipengaruhi oleh berbagai faktor seperti jenis lamun, kondisi substrat, musim, pasang surut, kekuatan energi gelombang, kandungan bahan organik dalam sedimen serta faktor lingkungan lainnya. Selain itu kepadatan lamun tinggi di perairan Pantai Prawean juga disebabkan karena lokasi Pantai Prawean pada saat pengambilan data, lokasi tersebut terlindung dari musim barat sehingga lamun di Pantai Prawean masih dapat ditemukan dalam jumlah yang banyak. Menurut Yusuf et al. (2012) arus yang lemah mengakibatkan pengadukan di substrat sedimen cenderung kecil yang megakibatkan kandungan nitrat dalam sedimen juga semakin tinggi dan juga sebaliknya.

Persentase tutupan lamun tertinggi di pantai Prawean Jepara terdapat pada stasiun II dengan rata-rata sebesar 79,98 \% $\pm 6,96$ termasuk kedalam kategori sangat padat. Persentase terendah ditemukan pada stasiun I dengan nilai rerata yaitu sebesar 50,85\% $\pm 20,07$ termasuk kategori padat dan stasiun III dengan rerata penutupan sebesar $62,10 \pm 5,77$ kategori padat. Tingginya persentase penutupan lamun pada stasiun II dipengaruhi oleh tingginya kepadatan jenis lamun pada stasiun ini. Stasiun II merupakan habitat yang cocok bagi beberapa jenis lamun untuk tumbuh dan berkembang (Handayani et al., 2016). Cymodocea serrulata memberi pengaruh lebih besar terhadap persentase tutupan.

Parameter pendukung penelitian di perairan Pantai Prawean Jepara diperoleh data Salinitas berkisar antara 30,3- 33,6 ppt. Parameter Salinitas DO didapatkan 7,06- 7,02 mg/L. Parameter pH berkisar antara 7- 8 dan parameter suhu berkisar antara 30,1-31,3 ${ }^{\circ} \mathrm{C}$. Kisaran suhu tersebut termasuk kisaran yang optimal untuk pertumbuhan lamun. Kisaran suhu yang melebihi $30{ }^{\circ} \mathrm{C}$ ini disebabkan topografi perairan yang dangkal sehingga sinar matahari mampu menembus perairan sampai ke dasar. Kondisi perairan kemudian menjadi hangat seiring lamanya penyinaran sinar matahari (Handayani et al., 2016). Sesuai dengan hasil penelitian kedalaman yang berkisar antara 0,4- 0,5 $\mathrm{m}$ yang masih dapat ditembus sinar matahari sehingga proses fotosintesis dapat berlangsung secara optimum. Menurut Effendi (2003) pembentukan nutrien berlangsung cepat pada suhu yang semakin tinggi dengan $\mathrm{pH}$ yang cenderung turun. Ini sesuai dengan hasil penelitian pengukuran suhu dan $\mathrm{pH}$ yang optimum pada penelitian kali ini. Pengukuran parameter arus didapatkan kisaran 0,23- 0,30 m/s. Menurut Yusuf et al., (2012) arus yang lemah mengakibatkan pengadukan di substrat sedimen cenderung kecil yang megakibatkan kandungan nitrat dalam sedimen juga semakin tinggi dan juga sebaliknya.

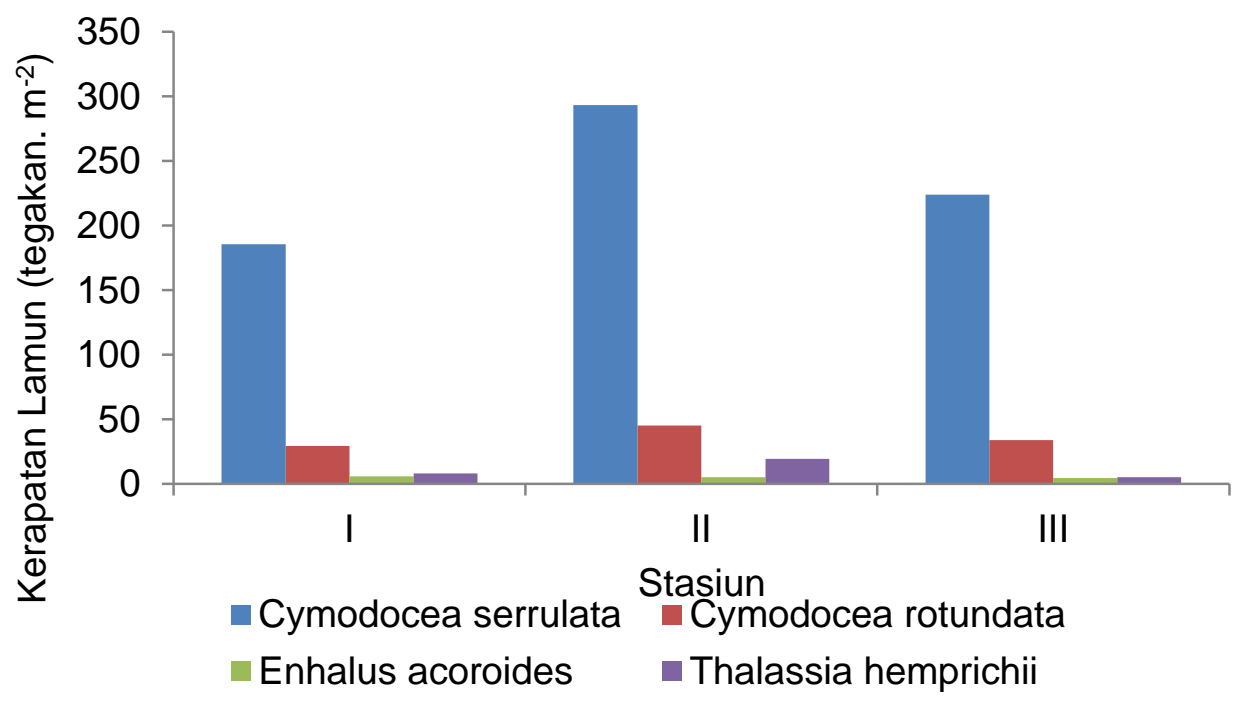

Gambar 4. Tingkat Kerapatan lamun di perairan Pantai Prawean, Jepara 


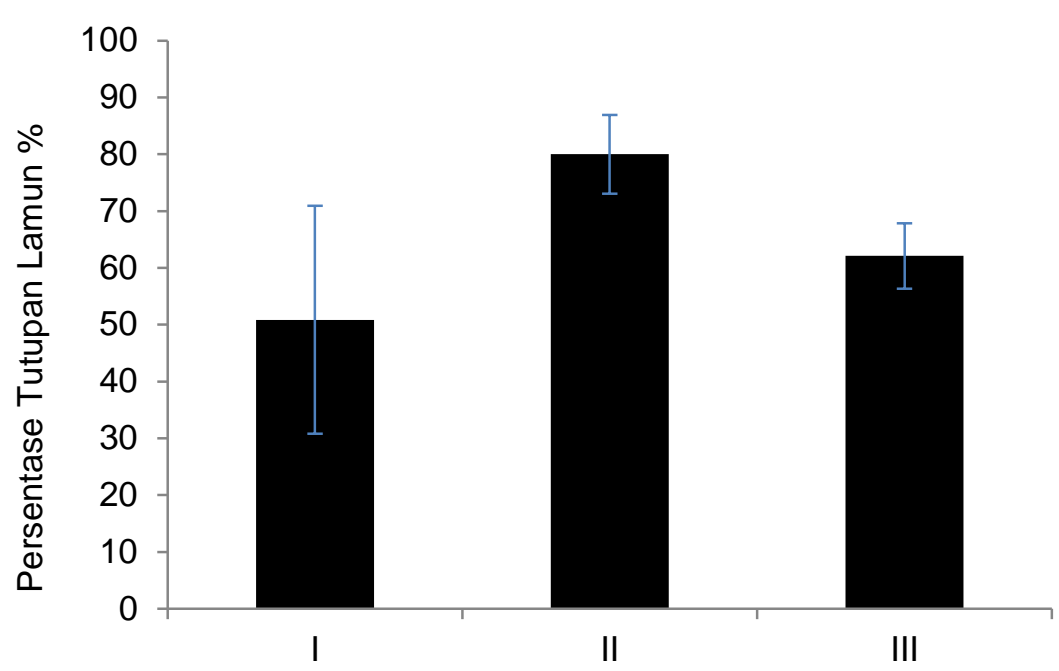

Gambar 5. Penutupan Lamun pada setiap Stasiun di Perairan Pantai Prawean, Jepara

Substrat pada lokasi penelitian ketiga stasiun memiliki klasifikasi: kerikil berkisar 5,48$20,58 \%$, pasir kasar berkisar 10,82- 20\%, pasir halus berkisar 47,58-60,29\%, dan lanau berkisar $12,66-23,41 \%$ dengan tipe substrat bertipe pasir.

\section{Hubungan Kandungan Nitrat dan Fosfat terhadap Kerapatan Lamun}

Berdasarkan analisis ini terdapat hubungan sangat kuat positif antara nutrien berupa nitrat dan fosfat dengan kepadatan. Nilai koefisien determinasi adalah $R^{2}=0,949$ artinya Kepadatan lamun dipengaruhi oleh adanya nutrien (nitrat dan fosfat) sebesar 94,9\%. Sisanya 5,1\% dipengaruhi faktor lain. Nilai koefisien korelasi adalah $R=0,974$. Artinya terdapat hubungan yang cukup erat karena 0,974 sudah mendekati nilai 1 . Persamannya $y=10,505-3,887$ (nitrat) 259,131 (fosfat). Berdasarkan hasil uji regresi tersebut, menunjukkan bahwa nilai titik potong diperoleh sebesar 10,505 artinya jika nitrat dan fosfat nilainya 0 , maka nilai kepadatan lamun adalah positif sebesar 10,505 . Koefisien regresi variabel fosfat $(X 1)$ diperoleh sebesar $-3,887$ artinya jika nitrat mengalami penurunan satu satuan, maka kepadatan akan mengalami penurunan sebesar -63,887 Sedangkan koefisien regresi variabel nitrat (X2) sebesar -259,131 artinya jika fosfat mengalami penurunan satu satuan, maka kepadatan akan mengalami penurunan pula sebesar $-259,131$ satuan. Hasil Anova didapatkan nilai $F$ yaitu 55,341 dan signifikansinya yaitu 0,00 yang menandakan semua variabel independen secara simultan merupakan penjelas yang signifikan terhadap variabel dependen $(<0,05)$. Pada uji t didapatkan nilai nitrat: $-8,874$ dengan signifikansinya yaitu 0,00 dan fosfat: $-1,185$ dan siignifikansinya 0,281 . Menandakan nitrat merupakan koefisien yang berpengaruh terhadap kerapatan lamun karena $(\mathrm{sig}<0,05)$.

Nitrat dan fosfat pada sedimen merupakan unsur esensial bagi tumbuhan tingkat tinggi dan alga, sehingga unsur ini menjadi faktor pembatas bagi tumbuhan dan alga akuatik serta mempengaruhi tingkat produktifitas perairan. Berdasarkan hasil analisis regresi berganda didapatkan kandungan Nitrat memberikan kontribusi secara nyata terhadap kerapatan lamun dibandingkan fosfat, Karena berdasarkan hasil penelitian didapatkan kandungan fosfat yang tinggi. Berdasarkan Keputusan menteri Lingkungan Hidup nomor 51 tahun 2004 tentang baku mutu, konsentrast maksimum fosfat $0,015 \mathrm{mg} / \mathrm{L}$ yang layak untuk kehidupan biota laut. Sesuai dengan pernyataan Handayani et al. (2016) Jika kandungan fosfat terus meningkat akan mempengaruhi penurunan efektifitas lamun untuk proses fotosintesis. Selain nitrat dan fosfat yang mempengaruhi pertumbuhan lamun, substrat juga mempengaruhi pertumbuhan lamun hall ini didukung oleh pernyataan Erftemeijer dan Middelburg (1993) menjelaskan bahwa semakin kecil ukuran sedimen, maka akan semakin besar ketersediaan nutrien di substrat tersebut. Kandungan nutrien Nitrat dan Fosfat berpengaruh terhadap pertumbuhan lamun karena nutrien yang terdapat pada sedimen langsung diserap oleh sistem perakaran lamun yang membantu pertumbuhan lamun itu sendiri. Sesuai dengan pernyataan Ertmeijer (1993) bahwa tumbuhan lamun lebih dominan memanfaatkan unsur nitrat dalam air poros dan sedimen melalui akar dan rhizoma daripada nitrat pada kolom air. Kandungan nitrat dan fosfat suatu perairan dijadikan tolok ukur kesuburan perairan karena 
semakin optimal kandungan nitrat dan fosfat suatu perairan maka semakin melimpah terhadap pertumbuhan tumbuhan (Mustofa, 2015).

\section{KESIMPULAN}

Terdapat hubungan antara kandungan nitrat dan fosfat pada substrat terhadap kepadatan lamun di Perairan Pantai Prawean Jepara. Hubungan sangat kuat positif antara nutrien dengan kepadatan lamun pada lokasi penelitian, $r=0,974$ dengan nilai koefisien determinasi adalah $R^{2}=$ 0,949 dengan persamaan $y=10,505-3,877$ (nitrat) $-259,131$ (fosfat) .Nitrat merupakan koefisien yang memberikian kontribusi nyata terhadap kerapatan lamun karena didapatkan nilai signifikansinya yaitu $0,00(<0,05)$.

\section{DAFTAR PUSTAKA}

Bennett, E.M., Carpenter, S.R. \& Caraco, N. F. 2001. Human Impact on Erodable Phosphorus and Eutrophication : A Global Perspective', BioScience, 51(3):227-234.

Cambridge, M.L., \& G.A. Kendrick. 2009. Contrasting Responses of Seagrass Transplants (Posidonia australis) to Nitrogen, Phosphorus and Iron Addition in an Estuary and a Coastal Embayment. Journal of Experimental Marine Biology and Ecology : 371:34-41.

Effendi H. 2003. Telaah Kualitas Air. Bagi Pengeloaan Dan Sumberdaya Lingkungan. Kanisius. Yogyakarta.

English, S., Wilkinson, C., \& Baker, V. 1997. Survey Manual for Tropical Marine Resources, 2nd Edition. Australian Institute of Marine Science Townsville.

Erftemeijer, P.L.A., Middelburg., \& Jack, J. 1993. Sediment-nutrient Interaction In Tropical Seagrass Beds: a Comparasion between a Terigeneus and a Carbonat Sedimentary Environmental in South Sulawesi. Marine Progress Series, 102:187-198

Fachrul, M., Haeruman, H., \& Sitepu, L.C. 2005. Komunitas Fitoplankton sebagai Bioindikator Kualitas Perairan Teluk Jakarta. Universitas Indonesia. Jakarta.

Handayani, D.R., Armid., \& Emiryati. 2016. Hubungan Kandungan Nutrien DalamSubstrat Terhadap Kepadatan Lamun Di Perairan Desa Lalowaru Kecamatan Moramo Utara. Jurnal Sapa Laut. 1(2):42-53

Hartati, R., Djunaedi, A. \& Haryadi. 2012. Struktur Komunitas Padang Lamun di Perairan Pulau Kumbang. Kepulauan Karimunjawa. IImu Kelautan. 17(4):217- 225

Hillman, K., Walker, D.J., Larkum, A.W.D. \& Mc Comb, A.J. 1989. Productivity and Nutrients Limitation on Seagrasses. Biology of Seagrasses. Elsevier Science Publishers. Netherland.

McKenzie, L.J. \& Campbell, S.J. 2003. Manual for Community (Citizen) Monitoring of Seagrass Habitat. Wester Pasific Edition. Seagrass Wach. Department of Primary Industries Queensland : Australia.

Mustofa, A. 2015. Kandungan Nitrat dan Pospat Sebagai Faktor Tingkat Kesuburan Perairan Pantai. J. DISPORTEK. Teknologi UNISNU Jepara 6(1): 13-19.

Raymont, J.E.G. 1961. Plankton and Produktivity In The Ocea, 2nd Edition, Vol 1 phyro, Pergamon Press, Oxford England.

Stapel, J., Aarts, T.L., Van Duynhoven, B.H., de Groot, J.D., van den Hoogen, P.H. \& Hemminga, M.A., 1996. Nutrient uptake by leaves and roots of the seagrass Thalassia hemprichii in the Spermonde Archipelago, Indonesia. Marine Ecology Progress Series, 134, pp.195-206.

Sugiyono. 2009. Metode Penelitian Kuantitatif, Kualitatif dan R\&D.Alfabeta : Jakarta.

Yunitha, Alphina., Yusli, W., \& Fredinan, Y. 2014. Diameter Substrat dan Jenis Lamun di Pesisir Bahoi Minahasa Utara: Sebuah Analisis Korelasi. Jurnal IImu Pertanian Indonesia. 19(3): 130-135

Yusuf, M. Gentur, H, Muslim, Wulandari, S. \& Heriyoso, 2012. Karakteristik Pola Arus Dalam Kaitannya Dengan Kondisi Kualitas Perairan Dan Kelimpahan Fitoplankton Di Perairan Kawasan Taman Nasional Laut Karimunjawa. Buletin Oseanografi Marina. 1:63-74. 